\title{
SISTEM PENDUKUNG KEPUTUSAN DENGAN METODA MULTI-CRITERIA DECISION MAKING ( MCDM)
}

\author{
Nur Heri Cahyana \\ Prodi Teknik Informatika UPN "Veteran" Yogyakarta \\ Jl. Babarsari 2 Tambakbayan 55281 Telp (0274) 485323 \\ email : dsnurheri@gmail.com
}

\begin{abstract}
Multicriteria decision making methods MCDM technique takes preference to the idealsolution, TOPSIS is one of the more widely used MCDM methods in decision supportsystems. For the purpose of the work, the modified TOPSIS method into a form that canbe used for the implementation of web-based medical diagnosis system. In modifying TOPSIS method, we utilize fuzzy logic te so users can more accurately describe their symptoms. Data provided by the modified TOPSIS method is often in proportion and maytake considerable time to produce alternative rankings. TOPSIS is suitable for parallel computing due to a combination of matrix calculations. Therefore implemented a parallelcomputer so that a large number of input data can be handled simultaneously, it reduces the overall execution time. In addition, making the system more accessible MCDM. Webbased medical diagnosis system including user interface dynamically generated.
\end{abstract}

\section{Keywords: Decision Support Systems, Multi-Criteria, MCDM}

Pengambilan keputusan multikriteria metode MCDM Teknik mengambil preferensi ke solusi ideal, TOPSIS adalah salah satu metode MCDM lebih banyak digunakan dalam sistem pendukung pengambilan keputusan. Untuk tujuan pekerjaan, metode TOPSIS dimodifikasi menjadi bentuk yang bisa digunakan untuk pelaksanaan sistem diagnosa medis berbasis web. dalam memodifikasi metode TOPSIS, kita te memanfaatkan logika fuzzy sehingga pengguna dapat lebih akurat menggambarkan gejala mereka. Data yang diberikan dengan metode TOPSIS dimodifikasi sering dalam proporsi dan dapat mengambil waktu cukup banyak untuk menghasilkan peringkat alternatif. TOPSIS cocok untuk komputasi paralel karena kombinasi dari perhitungan matriks. Oleh karena itu diimplementasikan komputer paralel sehingga sejumlah besar data input dapat ditangani secara bersamaan, maka mengurangi waktu eksekusi secara keseluruhan. Selain itu, membuat sistem MCDM yang lebih mudah diakses. Sistem diagnosis medis berbasis web termasuk antarmuka pengguna yang dihasilkan secara dinamis.

Kata kunci : Sistem Pendukung Keputusan, Multikriteria, MCDM

\section{PENDAHULUAN}

Masalah diagnosis medis dapat dinyatakan sebagai berikut: diberikan satu set data klinis gejala dan sinyal, atau hasil tes yang dilakukan pada pasien, menilai situasi patologis dan mengidentifikasi penyakit tertentu membenarkan temuan. Sistem pendukung keputusan yang penting untuk professi medis, mereka bisa memberikan dukungan empiris untuk memperkuat keputusan penting. beberapa teknik computerais, umumnya dikenal sebagai sistem pakar, telah diusulkan di masa lalu untuk membantu memecahkan problem diagnostik, beberapa pendekatan, yang melakukan secara formal yang berbeda untuk domain pemodelan pengetahuan, termasuk berbasis peraturan atau sistem produksi, sistem berbasis frame, jaringan semantik, saraf jaringan, dan jaringan kepercayaan Bayes, kelemahan dari pendekatan ini termasuk kesulitan memperbarui basis pengetahuan dengan informasi baru, respon waktu yang lama, terutama untuk beberapa pengguna secara bersamaan, kesulitan penggunaan, dan akhirnya rendahnya kualitas diagnosis dalam beberapa kasus. 
Satu set metode yang biasa digunakan untuk membuat keputusan di berbagai bidang ilmu pengetahuan dan pendidikan adalah keputusan multikriteria. Dalam hal ini, sistem pendukung keputusan diperkenal penggunakan MCDM untuk menganalisis serangkaian gejala dan tingkat keparahan dan memberikan diagnosis medis. Metode MCDM sering digunakan untuk menentukan peringkat alternatif yang diberikan dengan mengevaluasi kriteria dengan alternatif. Kami mengusulkan mengobati penyakit manusia sebagai alternatif dan informasi pasien individu sebagai kriteria untuk digunakan metode MCDM. Metode MCDM mengevaluasi berbagai penyakit manusia terhadap informasi pasien yang diberikan dan menghasilkan daftar penyakit yang dapat mempengaruhi pasien, dalam rangka kemungkinan. Data yang diberikan untuk sistem ini seringkali sangat banyak, dapat mengambil banyak kriteria. Diimplementasikan secara paralel sehingga sejumlah besar data input dapat ditangani secara bersamaan, sehingga mengurangi waktu eksekusi secara keseluruhan dan meningkatkan throughput. Lebih khusus, kami telah memodifikasi teknik standar preferensi TOPSIS ke solusi ideal MCDM. Satu modifikasi telah menjadi pengenalan logika fuzzy, yang memungkinkan penggunaan bahasa alami untuk mewakili keparahan gejala yang dialami pasien. Satu lainnya modifikasi adalah pengenalan suatu matriks apriori penyakit dan sistem yang terkait ke dalam TOPSIS. Biasanya metode TOPSIS dimulai dengan matriks alternatif difinisi user dan kriteria, kemudian alternatif dibandingkan terhadap satu sama lain untuk membentuk peringkat penyakit dalam rangka kemungkinan. Kami telah memodifikasi TOPSIS untuk mulai dengan matriks sebelumnya ada yang tidak ditentukan pengguna; tetapi itu adalah standar, atau apriori, matriks penyakit yang berisi skor untuk setiap per gejala penyakit. Pengguna kemudian memberikan sebuah array nilai pergejala, yang dibandingkan dengan matriks apriori untuk menemukan peringkat penyakit bila dibandingkan dengan gejala yang diberikan pengguna. Sistem diagnostik menggunakan halaman web dinamis untuk berinteraksi dengan pengguna akhir. Melalui media web ini, perhitungan disampaikan dalam dua tahap. Sebuah antarmuka pengguna dinamis yang dihasilkan digunakan oleh sebuah aplikasi web server untuk memberikan sisi klien sistem. Sisi server dari sistem adalah CGI (Antarmuka Common Gateway) yang berinteraksi dengan Pesan Passing Interface (MPI).

\section{BAHAN DAN METODE}

\subsection{Sistem Pendukung Keputusan}

Sistem Pendukung Keputusan (SPK) merupakan suatu sistem interaktif yang membantu manajer dalam mengambil keputusan melalui penggunaan data dan model keputusan untuk memecahkan masalah-masalah yang sifatnya semi terstruktur dan tidak terstruktur Suatu SPK memiliki tiga subsistem utama yang menentukan kapabilitas teknis SPK tersebut, yaitu

1) Subsistem Manajemen Basis Data (database)

Subsistem ini merupakan komponen SPK penyedia data bagi sistem. Data tersebut disimpan dalam basis data yang diorganisasikan oleh DBMS. Basis data dalam SPK berasal dari sumber internal dan eksternal

2) Subsistem Manajemen Basis Data Model (modelbase)

Model adalah peniruan dari alam nyata. Model ini dikelola oleh model base.

3) Subsistem Basis Dialog (user system interface)

Melalui sistem dialog inilah sistem diartikulasikan dan diimplementasikan sehingga pemakai dapat berkomunikasi dengan sistem yang dirancang.

\subsection{Keputusan multikriteria}

Kategori dari metode TOPSIS (Technique For Others Reference by Similarity to Ideal Solution) adalah kategori MCDM yaitu teknik pengambilan keputusan dari beberapa pilihan alternatif yang ada ,khususnya MADM(Multi Attribute Decision Making).TOPSIS bertujuan untuk menentukan solusi ideal positif dan solusi ideal negatif. Solusi ideal positif memaksimalkan kriteria manfaat dan meminimalkan kriteria biaya, sedangkan solusi ideal negatif memaksimalkan kriteria biaya dan meminimalkan kriteria manfaat

Metode MCDM adalah algoritma yang menentukan peringkat alternatif yang diberikan ketika semua alternatif yang diberikan dibandingkan terhadap kriteria yang sama. MCDM adalah metode pengambilan keputusan yang agak populer digunakan di banyak bidang seperti pendidikan dan manajemen sciences. komponen umum ditemukan di kebanyakan alternatif algoritma MCDM, kriteria, bobot, dan matriks keputusan. Alternatif adalah representasi dari pilihan yang diberikan kepada pengguna. Sebagai contoh, MCDM digunakan untuk halaman web. Setiap halaman web akan menjadi alternatif. Kriteria yang dipilih untuk membantu 
mengevaluasi setiap halaman web. Contoh kriteria adalah tata letak, desain, kegunaan, dan sebagainya. Kriteria masing-masing juga memiliki bobot. Web tertentu mungkin menentukan bahwa kegunaan dari suatu halaman web yang lebih penting dari layout dan tata letak karena akan diberikan bobot yang lebih besar ketika menentukan halaman peringkat. Setelah alternatif kriteria, dan bobot yang ditentukan.

\subsection{Teknik Preferensi}

TOPSIS menggunakan prinsip bahwa alternatif yang terpilih tidak hanya mempunyai jarak terpendek dari solusi ideal positif, namun juga memiliki jarak terpanjang dari solusi ideal negatif. Konsep ini banyak digunakan untuk menyelesaikan masalah keputusan secara praktis. Konsepnya sederhana dan mudah dipahami, komputasinya efisien dan memiliki kemampuan untuk mengukur kinerja relatif dari alternatif-alternatif keputusan kedalam bentuk matematis yang sederhana. Konsep fundamental dari metode ini adalah menentukan jarak Euclide terpendek dari solusi ideal positif dan jarak. Langkah-langkah:

1) Membangun normalized decision matrix. Elemen rij hasil dari normalisasi decision matrix $R$ dengan metode Euclidean length of a vector adalah:

$$
r_{i j}=\frac{x_{i j}}{\sqrt{\sum_{i=1}^{m} x_{i j}^{2}}}
$$

2) Membangun weighted normalized decision matrix. Dengan bobot $W=(w 1$, w2,....,wn), maka normalisasi bobot matriks $V$ adalah:

$$
\mathrm{V}=\left[\begin{array}{cccc}
w_{1} r_{11} & w_{2} r_{12} & \ldots & w_{n} r_{1 n} \\
w_{1} r_{21} & & & \\
\cdot & & & \\
w_{1} m_{1} & w_{2} r_{\mathrm{m} 2} & \ldots & w_{n} r_{\mathrm{mn}}
\end{array}\right]
$$

3) Menentukan solusi ideal dan solusi ideal negatif. Solusi ideal dinotasikan $A^{*}$,

$$
\begin{aligned}
& A^{*}=\left\{\left(\max v_{i j} \mid j € J\right),\left(\min v_{i j} \mid j € J^{\prime}\right),\right. \\
& i=1,2,3, \ldots, m\}=\left\{v_{1}, v_{2}, \ldots, v_{n^{*}}\right\} \\
& A-=\left\{\left(\min v_{i j} \mid j € J\right),\left(\max v_{i j} j € J\right)\right.
\end{aligned}
$$

sedangkan solusi ideal negatif dinotasikan $A-i=1,2,3, \ldots, m\}=\left\{v_{1}^{-}, v_{2}^{-}, \ldots, v_{n}^{-}\right\}$

$$
\begin{aligned}
& \mathrm{J}=\{\mathrm{j}=1,2,3, \ldots, \mathrm{n} \text { dan } \mathrm{j} \text { merupakan benefit criteria }\} \\
& \mathrm{J}^{\prime}=\{\mathrm{j}=1,2,3, \ldots, \mathrm{n} \text { dan } \mathrm{j} \text { merupakan cost criteria }\}
\end{aligned}
$$

4) Menghitung separasi. $\mathrm{Si}^{\star}$ adalah jarak (dalam pandangan Euclidean) alternatif dari solusi ideal didefinisikan sebagai:

$$
S_{i^{*}}=\sqrt{\sum_{j=1}^{n}\left(v_{i j}-v_{j}^{*}\right)^{2}} \text {, dengan } i=1,2,3, \ldots, m
$$

Dan jarak terhadap solusi negatif-ideal didefinisikan sebagai:

$$
S_{i^{-}}=\sqrt{\sum_{j=1}^{n}\left(v_{i j}-v_{j}^{-}\right)^{2}} \text {, dengan } i=1,2,3, \ldots ., m
$$

5) Menghitung kedekatan relatif terhadap solusi ideal

$$
C_{i^{*}}=\frac{S_{i^{-}}}{S_{i^{*}}+S_{i^{-}}} \text {, dengan } 0<C_{i^{*}}<1 \text { dan } i=1,2,3, \ldots, m
$$

6) Merangking Alternatif .Alternatif dapat dirangking berdasarkan urutan $\mathrm{Ci}^{*}$. Maka dari itu, alternatif terbaik adalah salah satu yang berjarak terpendek terhadap solusi ideal dan berjarak terjauh dengan solusi negatif-ideal. 


\subsection{Modifikasi Metode TOPSIS}

Untuk keperluan maka, metode TOPSIS dimodifikasi. Biasanya solusi ideal terbentuk dari alternatif yang diberikan dalam keputusan matriks. Solusi-solusi yang ideal ini kemudian digunakan untuk memberikan peringkat alternatif bila dibandingkan terhadap satu sama lain. Namun, untuk sistem diagnosis berbasis web diusulkan, pengguna diminta untuk memberikan masukan bagi berbagai gejala. Input yang diberikan kepada sistem oleh pengguna digunakan sebagai solusi ideal. Matriks keputusan itu sendiri adalah terbentuk dari alternatif yang pada kenyataan penyakit. Kriteria per alternatif gejala umum yang berlaku untuk semua penyakit. Masukan pengguna adalah kemudian dicocokkan dengan nilai-nilai yang telah ditentukan untuk penyakit masing-masing, yang merupakan matriks apriori, dan entri pengguna dibandingkan, dan penyakit yang memiliki skor gejala yang paling dekat untuk masukan pengguna adalah penyakit yang dipilih.

Masalah yang baru saja dijelaskan cocok untuk metode TOPSIS. Biasanya Metode TOPSIS dimulai dengan matriks user-defined alternatif dan kriteria, maka alternatif dibandingkan terhadap satu sama lain untuk membentuk peringkat.

Metode MCDM sering menggunakan sistem penilaian yang tidak inheren. Sebagai contoh, perbedaan antara nyeri ringan dan rasa sakit adalah fungsi secara bertahap dan tidak secara. Karena perbedaan antara kriteria dan alternatif sering kabur, logika fuzzy adalah dimasukkan ke metode MCDM TOPSIS. Pusat daerah algoritma digunakan untuk defuzzification setelah eksekusi dari algoritma TOPSIS. pusat dari persamaan area yang digunakan

$$
\begin{aligned}
f_{M}(x) & = \begin{cases}\frac{(x-a)}{(b-a)}, & a \leq x \leq b \\
\frac{(x-c)}{(b-c)}, & b \leq c \leq c \\
0, & \text { otherwise }\end{cases} \\
D_{i j} & =\left[\left(U_{i j}-L_{i j}\right)+\left(M_{i j}-L_{i j}\right)\right] / 3+L_{i j}
\end{aligned}
$$

Tabel.1.Nilai normal fuzzy diganti dengan nilai yang teratur menggunakan metoda pusat area.

\begin{tabular}{lccccccccc}
\hline & \multicolumn{10}{c}{ Criteria and weights } \\
\cline { 2 - 10 } & C1 & C2 & C3 & C4 & C5 & C6 & C7 & C9 & C10 \\
\hline Alternatives & 0.00 & 0.00 & 0.00 & 0.00 & 0.00 & 0.00 & 0.00 & 0.00 & 0.00 \\
Acute glaucoma & 0.00 & 0.00 & 0.00 & 0.10 & 0.13 & 0.20 & 1.00 & 0.00 & 0.15 \\
Acute uveitis & 0.22 & 0.81 & 0.44 & 0.22 & 0.13 & 0.20 & 0.00 & 0.00 & 0.23 \\
Bacterial conjunctivitis & 0.00 & 0.00 & 0.00 & 0.22 & 0.13 & 0.20 & 0.00 & 0.39 & 0.23 \\
Corneal disorder & 0.55 & 0.19 & 0.00 & 0.22 & 0.35 & 0.20 & 0.00 & 0.22 & 0.23 \\
Normal condition & 0.22 & 0.00 & 0.56 & 0.22 & 0.26 & 0.20 & 0.00 & 0.39 & 0.15 \\
Viral conjunctivitis & 0.00 & 0.00 & 0.00 & 0.00 & 0.00 & 0.00 & 0.00 & 0.00 & 0.00 \\
\hline
\end{tabular}

Setiap pada komputer cluster pertama menghitung berapa banyak nomor floating point.

\section{IMPLEMENTASI DAN PEMBAHASAN}

Untuk memberikan kemudahan pada bagian pengguna, antarmuka dibuat banyak fitur dan pilihan, interaksi dilakukan melalui Internet, dikirim ke pengguna menggunakan web server, dan dilihat oleh pengguna melalui web browser. Karena sistem yang dijelaskan berpotensi melayani basis pengguna yang besar, kami memperkenalkan algoritma paralel yang telah dijelaskan sebelumnya untuk meningkatkan kinerja dari sistem dan mengurangi waktu yang dibutuhkan untuk setiap diagnostik individu. Dengan cara ini meminimalkan pembelajaran yang dibutuhkan oleh pengguna baru dan membuat antarmuka lebih diakses. Web dipilih sebagai platform pengiriman. Akibatnya perangkat dengan koneksi ke World Wide Web adalah mampu berinteraksi dengan sistem. 
3.1. Implementasi

Interaksi pengguna dicapai dengan memilih untuk setiap gejala representasi dari keparahan. Sebagai contoh, jika sistem diagnostik ini mengevaluasi penyakit mata, maka gejala yang akan diuji untuk tekanan intraokular. Bahasa alami representasi angka fuzzy direpresentasikan dalam antarmuka pengguna. Contoh dari interaksi pengguna diberikan pada Gambar 1

\begin{tabular}{|c|c|c|}
\hline Conjunctival infection & Comea & Discharge \\
\hline Please choose from belou $\checkmark$ & Please choose from below $\sim$ & Please choose from below \\
\hline Intraocular Pressure & Irritation & Light Sensitivity \\
\hline Please choose from belon $\sim$ & Please choose from below $\checkmark$ & Please choose from below \\
\hline $\begin{array}{l}\text { Please choose from below } \\
\text { Severe }\end{array}$ & Pupil Sire & Smear \\
\hline Moderate & Please choose from below $\checkmark$ & Please choose from below \\
\hline $\begin{array}{l}\text { Normal } \\
\text { Vision }\end{array}$ & & \\
\hline Please choose from below $\checkmark$ & & \\
\hline
\end{tabular}

Submit for Diognosis

Gambar 1. Interface untuk pengguna biasa

Nama gejala disimpan dalam satu tabel, bersama dengan nilai identifikasi yang unik. Antara tabel memiliki relasi satu-ke-satu untuk identifikasi. yang lain tabel komposit adalah nama pilihan sebagai output untuk keparahan masing-masing, dan link ke nilai fuzzy untuk dikaitkan dengan pilihan, yang disimpan dalam tabel ketiga Gambar 2

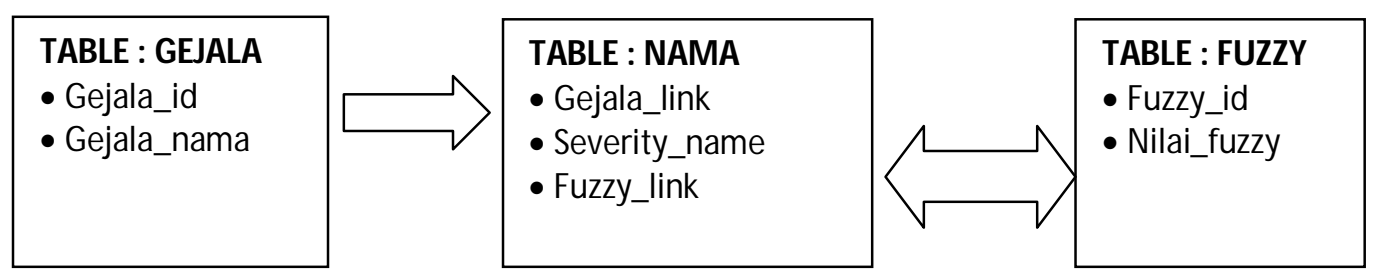

Gambar 2. Database representasi dari basis pengetahuan dinamis

Basis pengetahuan dilakukan dengan menggunakan MySQL. contoh kode SQL yang digunakan untuk mengisi antarmuka user pada Gambar 1. Fuzzy nomor disimpan sebagai string dalam koma, database

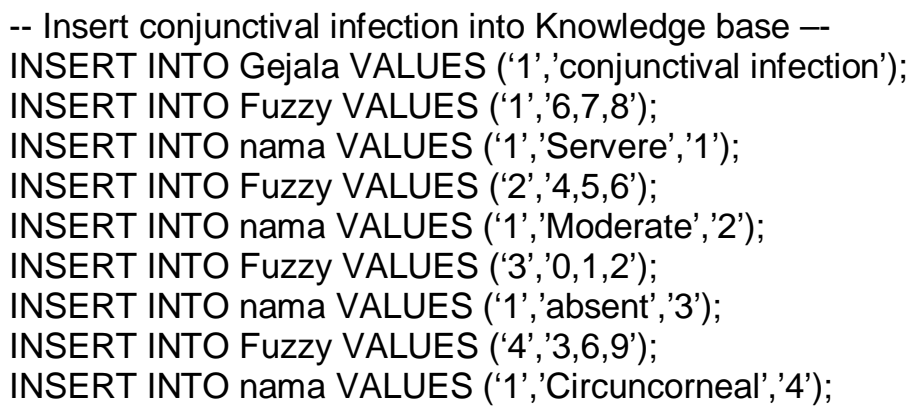

dibatasi. Pilihan keparahan tercantum dalam database, dan dapat diubah atau diklarifikasi tanpa mempengaruhi representasi numerik. Untuk mengekstrak data dari database dan membangun sebuah halaman HTML untuk interaksi pengguna, yang preprocessing hypertext 
bahasa PHP yang digunakan. Ketika sebuah pengguna akhir membuat koneksi ke sistem, halaman yang disediakan bagi pengguna interaksi dinamis. Untuk menyediakan antarmuka dinamis yang dihasilkan. Pada awal, koneksi dengan basis pengetahuan dan query untuk mengambil satu set data dari semua nilai-nilai yang akan digunakan. Setelah set data telah dihasilkan, semua yang tersisa adalah untuk melanjutkan data, salah satu gejala pada satu waktu, dan menghasilkan kombinasi kotak. Untuk setiap keparahan gejala yang berhubungan dengan gejala, sejumlah fuzzy adalah kode sebagai nilai pilihan dari tag HTML. Akibatnya, ketika pengguna mengklik menyerahkan tindakan tombol Mendiagnosa, tulisan membentuk nilai string fuzzy untuk setiap gejala ke modul CGI sisi server, yang akan memanfaatkan highperformance TOPSIS dimodifikasi algoritma untuk melakukan perhitungan dan mengembalikan hasil.

\section{KESIMPULAN}

Kompleksitas komputasi dari TOPSIS dimodifikasi adalah $\mathrm{O}\left(\mathrm{n}^{2}\right)$, Yang titik dasar perbandingan untuk implementasi. Dalam evaluasi, p mewakili jumlah node yang tersedia untuk pengolahan perhitungan. Oleh karena itu, kita dapat mendefinisikan efisiensi (E) sebagai waktu untuk algoritma seri (Tc), dibagi oleh produk dari waktu paralel $(\mathrm{Tp})$ dan $\mathrm{p}$.

Gejala dapat dibandingkan terhadap banyak gejala berbagai penyakit dan perbandingan dapat ditemukan antara penyakit yang telah ditetapkan dan gejala pengguna. Perbandingan ini bisa membantu dokter untuk mempersempit penyakit pasien mereka dan Oleh karena itu membantu memberikan diagnosis yang lebih benar dan tepat. Pada artikel ini, kami mengusulkan modifikasi dan penggunaan metode MCDM dikenal sebagai TOPSIS untuk mengimplementasikan sebuah alat berbasis web diagnostik medis. kami mengusulkan modifikasi dengan metode TOPSIS standar yang menggunakan matriks apriori, juga memanfaatkan logika fuzzy dalam metode TOPSIS, yang membuatnya lebih cocok dalam mendapatkan diagnosis medis.

\section{DAFTAR PUSTAKA}

Arfiani, retno laila sistem pendukung keputusan dengan menggunakan metode topsis http://misspikun.blogspot.com/2011/05/sistem-pendukung-keputusan-dengan.html

Hwang C.L, et.al (1981). Multiple Attribute Decission Making, Methods and Application,Spinger -Verlag.

Kadarsah S, et.al (1998). Sistem Pendukung Keputusan, Remaja Rosdakarya.

Kusumadewi S, et.al (2006). Fuzzy Multi-Attribute Decision Making (fuzzy MADM), Graha Ilmu 